\title{
A 10 kD BARLEY SEED PROTEIN HOMOLOGOUS WITH AN $\alpha$-AMYLASE INHIBITOR FROM INDIAN FINGER MILLET
}

\author{
by \\ BIRTE SVENSSON, KATSUHIKO ASANO ${ }^{2)}$, IB JONASSEN ${ }^{1,3)}$, \\ FLEMMING M. POULSEN, JOHN MUNDY ${ }^{1)}$ and IB SVENDSEN \\ Department of Chemistry, Carlsberg Laboratory, \\ Gamle Carlsberg Vej 10, DK-2500 Copenhagen Valby \\ " Department of Biotechnology, Carlsberg Research Laboratory \\ Gamle Carlsberg Vej 10, DK-2500 Copenhagen Valby \\ 2) Present address: Applied Bioscience Laboratory, Kirin Brewery Co., Ltd., \\ 2-2, Soujamachi 1chome, Maebashi-shi, 371 Japan \\ ${ }^{3)}$ Present address: Nordisk Insulinlaboratorium, DK-2820 Gentofte
}

Keywords: Hiproly barley, N-terminal amino acid sequence, enzyme inhibitor homology, NMR-spectroscopy, UV-difference spectroscopy

\begin{abstract}
A basic protein was isolated from aqueous extracts of barley seeds. It contains 91 amino acid residues including 8 half-cystines, but no phenylalanine or tryptophan; the calculated molecular weight is 9.694 . Amino acid composition and $\mathrm{N}$-terminal sequence show that the protein corresponds to the probable amylase/protease inhibitor (PAPI) encoded by a formerly described cDNA. The protein is $50 \%$ homologous with an $\alpha$-amylase inhibitor I-2 from seeds of Indian finger millet and it shows a distant homology with two Bowman Birk type protease inhibitors. However, the barley protein does not inhibit any of the enzymes tested. They include $\alpha$-amylases, a $\beta$-amylase. $\beta$-glucanases. serine proteases, a sulfhydryl protease, aspartate proteases. and serine carboxypeptidases. Nevertheless. difference UV-spectroscopy indicated that the protein interacts with porcine pancreatic $\alpha$-amylase. NMR-spectroscopy revealed that it possesses tertiary structure.
\end{abstract}

\section{INTRODUCTION}

The seèds of barley and other cereals contain numerous protease and $\alpha$-amylase inhibitors which during dormancy may protect against endogenous and exogenous hydrolytic activities. These inhibitors can be grouped into families based on sequence homologies and proposed common evolutionary origins (20):

1) Barley trypsin inhibitor family includes its namesake $\left(M_{r}-12,000\right)(26)$, a corn trypsin inhibitor (22), 5 barley CM-proteins (30) which include both trypsin and $\alpha$-amylase inhibitors (1), the wheat $\alpha$-amylase inhibitors (17), and a bifunctional $\alpha$-amylase/trypsin inhibitor from finger millet (4).

2) Soybean trypsin inhibitor (Kunitz) family includes the bifunctional $\alpha$-amylase/subtilisin inhibitors $\left(M_{r} \sim 21,000\right)$ of barley and wheat $(23,24)$.

3) Potato inhibitor I family includes chy-

Abbreviations: PAPI = probable amylase $/$ protease inhibitor; SDS-PAGE $=$ sodium dodecyl sulfate-polyacrylamide gel electrophoresis. 
motrypsin inhibitors 1 and $2\left(M_{r} \sim 9,000\right)$ of barley (33).

The present work describes the purification and some properties of a $M_{r} \sim 10,000$, basic protein from barley seeds. The corresponding full-length cDNA sequence (25) shows extensive homology with an inhibitor of porcine pancreatic $\alpha$-amylase from finger millet (I-2; $\mathrm{M}_{\mathrm{r}}$ $-12,000)$ which does not fit into any of the above inhibitor families (5). Furthermore, a distant evolutionary relationship is indicated to the trypsin inhibitory site region of two Bowman Birk type protease inhibitors isolated from eggplant (29) and Macrotyloma axillare (16), respectively. The protein was therefore named probable amylase/protease inhibitor (PAPI) (25). It was reported to be synthesized late during grain development and to be abundantly expressed in aleurone cells (25). We have been unable to identify a target enzyme for this protein.

\section{MATERIALS AND METHODS}

\subsection{Materials}

Barley seeds (H. vulgare, cv. Hiproly) were obtained from Carlsberg Plant breeding, Copenhagen, DK. DEAE- and CM-cellulose were DE-52 and CM-52 types from Whatman, Maidstone, U.K., Sephadex G-25, G-75 and low molecular weight electrophoresis calibration kit were from Pharmacia, Uppsala, Sweden. A. oryzae protease (Type XXIII), papain, trypsin, chymotrypsin, porcine pepsin, the wheat $\alpha$ amylase inhibitors, and $\alpha$-amylases from $B$. subtilis, A. oryzae and hog pancreas and barley $\beta$-amylase were from Sigma, St. Louis, MO. T. molitor and barley malt $\alpha$-amylases 1 and 2 were prepared as previously described (24). Subtilisin Carlsberg was a gift of Novo Industries. Yeast carboxypeptidase Y (12), malt carboxypeptidase I (3), yeast proteinase A (8) and barley chymotrypsin inhibitor $2(15,32)$ were prepared in this laboratory. All chemicals employed for reduction and alkylation of the polypeptide chain and for automated sequencing were obtained from previously described sources (13, $32,34)$.

\subsection{Purification of the $M_{r} \sim 10,000$ protein}

Whole barley flour $(13 \mathrm{~kg})$ was extracted at $4{ }^{\circ} \mathrm{C}$ for $2 \mathrm{~h}$ in water $(250 \mathrm{l})$ containing $2 \mathrm{~mm}$ ascorbic acid, at $\mathrm{pH} 6.5$, and left overnight. The supernatant was concentrated to $10 \mathrm{l}$ by ultrafiltration and subsequently added $\left(\mathrm{NH}_{4}\right)_{2} \mathrm{SO}_{4}$ to $20 \%$ saturation. The resultant supernatant was desalted by reversed osmosis, adjusted to $\mathrm{pH} 8.1$ and further fractionated essentially as described (14). The basic proteins appeared in the passthrough (5 1) from a DEAE-cellulose column $(25 \times 10 \mathrm{~cm})$, preequilibrated and washed with 30 mM-glycine pH 8.1, and they were subsequently separated on CM-cellulose at pH 6.5 (see legend to Figure 1 for details). Column fractions containing a $10 \mathrm{kD}$ protein, detected by SDS-PAGE, were pooled and purified by gel filtration on Sephadex G-75, eluted with 50 mm-sodium acetate, $\mathrm{pH} 4.9$, and then desalted on Sephadex G-25 eluted with $50 \mathrm{~mm}$-ammonium bicarbonate, followed by lyophilization.

\subsection{Analytical procedures}

The possible inhibition of trypsin, subtilisin Carlsberg, A. niger protease, and papain was tested for at pH 7.6 (120 mM-phosphate buffer) using casein as substrate (31). Inhibition of trypsin, chymotrypsin, and subtilisin Carlsberg was also examined in a pH-stat at $\mathrm{pH} 8.0$ and $22{ }^{\circ} \mathrm{C}$; $25 \mathrm{mM}$-tosylarginine methyl ester in 10 $\mathrm{mM}-\mathrm{KCl}$ was used as substrate for trypsin and $25 \mathrm{~mm}$-acetyltyrosine ethyl ester as substrate for the two other proteases. The proteases $(0.5$ $\mathrm{mg} \cdot \mathrm{ml}^{-1}$ ) were preincubated with up to 10 fold molar excess of PAPI at $22^{\circ} \mathrm{C}$ and $\mathrm{pH} 8.0$ for 30 min. Pepsin and yeast proteinase $A$ were assayed as previously described ( 8$)$. The enzymes $(100$ $\mathrm{nM}$ ) were preincubated at $\mathrm{pH} 2.5$ and 4.0 , respectively, with 70 to 150 fold molar excess of PAPI at $22{ }^{\circ} \mathrm{C}$ for $30 \mathrm{~min}$. The activity of yeast and malt carboxypeptidases was measured (3, 12) after incubation of the enzymes $(1 \mu \mathrm{M})$ with a 10 fold molar excess of PAPI in the respective assay buffers at $22{ }^{\circ} \mathrm{C}$ for $30 \mathrm{~min}$. Inhibition of amylases was measured as previously described (23). Inhibition of hydrolysis of barley $\beta$-glucan by barley $(1,3 ; 1,4)-\beta$-glucanase was tested by $D r$. G. Fincher (La Trobe University, Bundoora) using a viscometry assay and inhibition of re- 


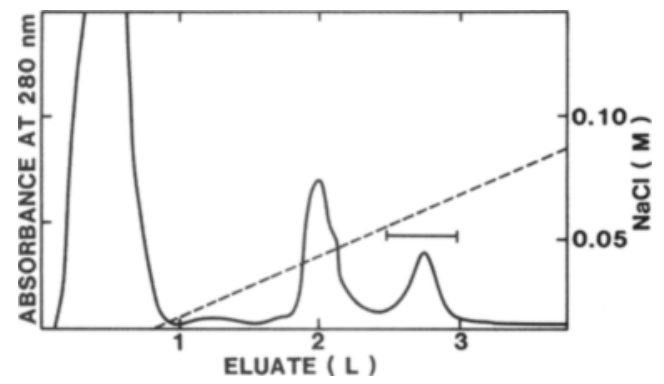

Figure 1. Isolation of PAPI by chromatography on $C M$-cellulose. $300 \mathrm{ml}$ of the eluant $\left(A_{280}=10.2\right)$ from a DEAE-cellulose column was adjusted to $\mathrm{pH} 6.5$ by phosphoric acid and applied to a column of CM-cellulose $(5 \times 22 \mathrm{~cm})$ preequilibrated in $20 \mathrm{~mm}$-sodium phosphate, pH 6.5 (see 2.2). After washing, proteins were eluted with a 31 linear gradient of zero to 0.1 $\mathrm{M}-\mathrm{NaCl}$ in the same buffer, at a flow rate of $130 \mathrm{ml} \cdot \mathrm{h}^{-1}$. Fractions containing a $10 \mathrm{kD}$ protein were pooled as indicated by the bar.

lease of reducing sugar from laminarin by barley 1,3- $\beta$-glucanase was tested for by Dr. M. BALLANCE (Department of Physiology, Carlsberg Laboratory) after $30 \mathrm{~min}$ preincubation with up to a 100 fold molar excess of PAPI over the respective enzymes.

The amino acid composition of the protein was determined after reduction and 2pyridylethylation (34). N-terminal automated sequencing was performed as previously described $(13,32)$. To determine the C-terminal amino acid residue, PAPI $(0.45 \mathrm{~mm}$ in $50 \mathrm{~mm}-\mathrm{N}$ ethylmorpholine acetate $\mathrm{pH}$ 6.5) was digested with $0.2 \mu \mathrm{M}$ malt carboxypeptidase I and 4 $\mu \mathrm{M}$-carboxypeptidase Y. Aliquots were removed, acidified and analyzed for liberated amino acids using a Durrum D-500 amino acid analyzer. Neutral carbohydrate and glucosamine were analyzed as previously described (34). SDS-PAGE in a $16 \%$ gel was performed a.m. LAEMMLI (19).

${ }^{1} \mathrm{H}-\mathrm{NMR}$ spectra were recorded on a Bruker AM $500 \mathrm{MHz}$ NMR spectrometer equipped with an Aspect 3000 computer. Chemical shift values are given in $\mathrm{ppm}$ with reference to the methyl resonance of 4,4-dimethyl-4-silapentane sulfonate.

UV-difference absorption spectra were ob-

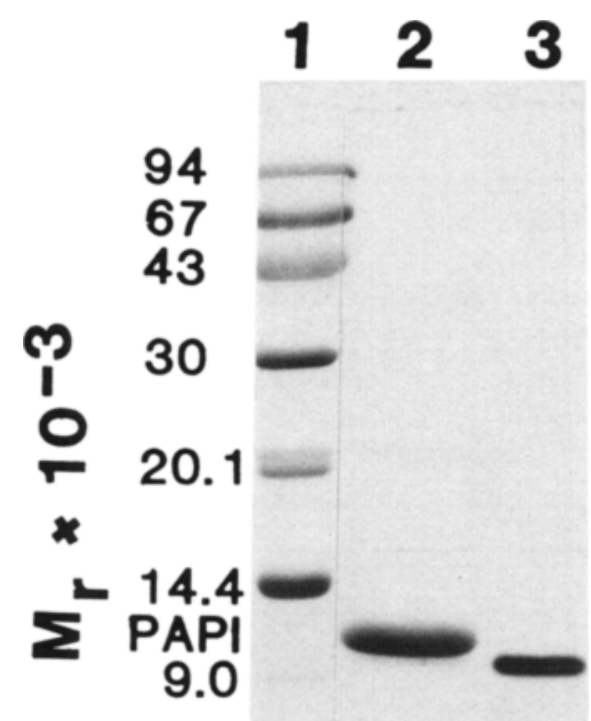

Figure 2. SDS-PAGE of PAPI (20 $\mu \mathrm{g}$, lane 2) after reduction and heat-denaturation. Standards were: phosphorylase b $(94,000)$, bovine serum albumin $(67,000)$, ovalbumin $(43,000)$, carbonic anhydrase $(30,000)$, soybean trypsin inhibitor $(21,000)$, $\alpha$-lactalbumin $(14,400)$ (lane 1), and barley chymotrypsin inhibitor $2(9,000)$ (lane 3 ).

tained with porcine pancreatic $\alpha$-amylase and PAPI in $0.02 \mathrm{M}$-sodium phosphate, $1 \mathrm{mM}-\mathrm{CaCl}_{2}$, $\mathrm{pH} 6.0$, at $25^{\circ} \mathrm{C}$ using double-chamber cuvettes. The spectra were recorded with a Cary 219 spectrophotometer after preincubation for 30 $\min$.

\section{RESULTS AND DISCUSSION}

The CM-cellulose chromatography (section 2.2) in the purification of the basic barley protein PAPI is shown in Figure 1. After gel filtration on Sephadex G-75 a yield of $650 \mathrm{mg}$ was obtained from $13 \mathrm{~kg}$ seeds. PAPI migrates as a single band in SDS-PAGE with apparent $\mathbf{M}_{\mathbf{1}} 10,200$ (Figure 2). Its amino acid composition (Table I) matches 
Table I. Amino acid composition of PAPI from barley.

\begin{tabular}{|c|c|c|c|}
\hline & \multicolumn{2}{|l|}{ PAPI } & \multirow[t]{2}{*}{ Ragi I-2 } \\
\hline & this study & $\mathrm{cDNA}^{\mathrm{e}}$ & \\
\hline Aspartic acid & $15.0(15)$ & 15 & 7 \\
\hline Threonine & $3.0^{\mathrm{a}}(3)$ & 3 & 2 \\
\hline Serine & $8.2^{\mathrm{a}}(8)$ & 8 & 16 \\
\hline Glutamic acid & $6.1 \quad(6)$ & 6 & 2 \\
\hline Proline & $6.3(6)$ & 6 & 4 \\
\hline Glycine & 9.1 (9) & 9 & 9 \\
\hline Alanine & 4.3 (4) & 4 & 20 \\
\hline Valine & $5.9^{b}(6)$ & 6 & 5 \\
\hline Methionine & 1.1 (1) & 1 & 0 \\
\hline Isoleucine & $6.1^{b}(6)$ & 6 & 5 \\
\hline Leucine & $6.3(6)$ & 6 & 5 \\
\hline Tyrosine & $2.6 \quad(3)$ & 3 & 2 \\
\hline Phenylalanine & $0.0 \quad(0)$ & 0 & 0 \\
\hline Histidine & $1.9 \quad(2)$ & 2 & 0 \\
\hline Half-cystine & $7.6^{c}(8)$ & 8 & 7 \\
\hline Lysine & $3.5 \quad(4)$ & 4 & 2 \\
\hline Arginine & $3.9 \quad(4)$ & 4 & 9 \\
\hline Tryptophan & $0.0^{\mathrm{d}}(0)$ & 0 & 0 \\
\hline Total residues & 91 & 91 & 95 \\
\hline \multicolumn{4}{|c|}{$\begin{array}{l}\text { a. Extrapolation to zero time of values from } 24,48 \text {, and } \\
72 \mathrm{~h} \text { hydrolysates. }\end{array}$} \\
\hline \multicolumn{4}{|c|}{ b. Value from 72 h hydrolysate. } \\
\hline \multicolumn{4}{|c|}{ c. Determined as 2-pyridylethyl-cysteine. } \\
\hline \multicolumn{4}{|c|}{$\begin{array}{l}\text { d. Estimated spectrophotometrically for a solution of } \\
\text { PAPI of known concentration (determined by amino } \\
\text { acid analysis) and assuming } \varepsilon_{280}=1,450 \mathrm{M}^{-1} \cdot \mathrm{cm}^{-1} \text { for } \\
\text { a tyrosyl residue. }\end{array}$} \\
\hline \multicolumn{4}{|c|}{$\begin{array}{l}\text { e. From the amino acid sequence of the proposed } \\
\text { mature form as deduced from the corresponding } \\
\text { cDNA sequence }(25) \text {. }\end{array}$} \\
\hline \multicolumn{4}{|c|}{$\begin{array}{l}\text { f. From the amino acid sequence of the ragi seed } \\
\alpha \text {-amylase inhibitor I-2 (5). }\end{array}$} \\
\hline
\end{tabular}

perfectly that given by the sequence deduced from the open reading frame of the corresponding full-length cDNA (25) after removal of a signal-sequence of 26 residues in consistence with rules for prediction of signal-cleavage sites (9). N-terminal sequence analysis of 2pyridylethylated PAPI identified 42 amino acid residues and tyrosine (in $90 \%$ yield) was released by carboxypeptidase $\mathrm{Y}$ and malt carboxypeptidase $I$ in combination, in accordance with the cDNA encoded (25) COOH-terminus (Figure 3). The molecular weight calculated from the amino acid composition is 9,694 in good agree-

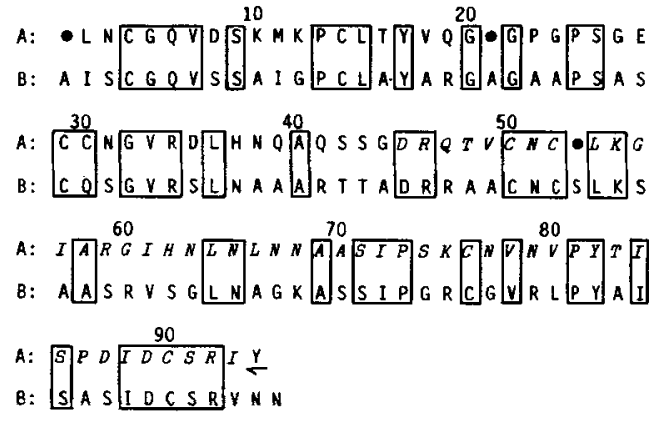

Figure 3. Amino acid sequence of A) PAPI from barley seeds compared with that of B) $\alpha$-amylase inhibitor I-2 from ragi (5). Residues deduced from a full-length cDNA encoding PAPI protein (25) are written in italics. Identical residues are boxed. $\bullet$ denotes a gap.

ment with the electrophoretic mobility. No neutral carbohydrate or glucosamine were detected in PAPI.

The appearance in the 'H-NMR spectrum (Figure 4) of PAPI of resonances outside the spectral envelope where resonances of the amino acid residues are expected, suggests that the protein is not randomly coiled. In particular, the resonances seen at ppm values lower than $0.75 \mathrm{ppm}$ in the region of aliphatic resonances, and the resonances seen at ppm values higher than $8.5 \mathrm{ppm}$ in the amide region suggest that the protein has a well defined tertiary structure.

The primary structure of PAPI shows, as published recently (25), extensive homology (Figure 3 ) with the porcine pancreatic $\alpha$-amyiase inhibitor I-2 from ragi seeds (5) and a distant homology with reactive site regions of two protease inhibitors $(16,29)$. PAPI and I-2 consist of polypeptide chains similar in size having 8 and 7 half-cystine residues, respectively, and both proteins lack phenylalanine and tryptophan (Table I). This sequence homology, together with homologies noted between several inhibitors of $\alpha$-amylases and inhibitors of proteases from cereal seeds $(26,30)$, prompted us to test whether PAPI inhibits a variety of a-amylases and proteases (see 2.3). The results of these assays were negative: we were unable to detect inhibition by PAPI of any of the enzymes tested. In addition, PAPI seemed not to degrade any of the employed substrates and it had no 

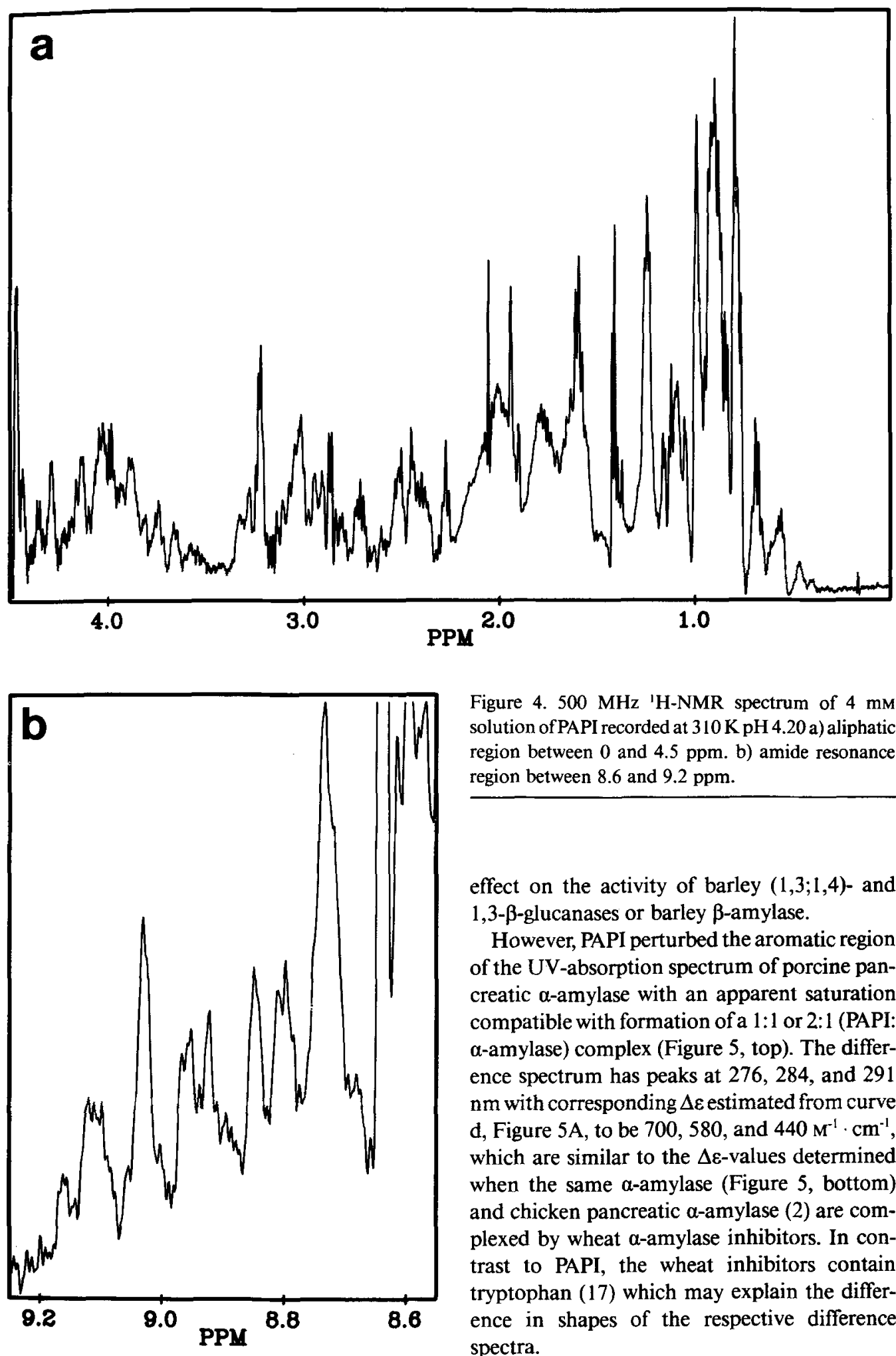

Figure 4. $500 \mathrm{MHz}$ 'H-NMR spectrum of $4 \mathrm{~mm}$ solution of PAPI recorded at $310 \mathrm{~K} \mathrm{pH} 4.20$ a) aliphatic region between 0 and $4.5 \mathrm{ppm}$. b) amide resonance region between 8.6 and $9.2 \mathrm{ppm}$.

effect on the activity of barley $(1,3 ; 1,4)$ - and $1,3-\beta$-glucanases or barley $\beta$-amylase.

However, PAPI perturbed the aromatic region of the UV-absorption spectrum of porcine pancreatic $\alpha$-amylase with an apparent saturation compatible with formation of a 1:1 or 2:1 (PAPI: $a$-amylase) complex (Figure 5, top). The difference spectrum has peaks at 276,284 , and 291 $\mathrm{nm}$ with corresponding $\Delta \varepsilon$ estimated from curve d, Figure $5 \mathrm{~A}$, to be 700,580 , and $440 \mathrm{M}^{-1} \cdot \mathrm{cm}^{-1}$, which are similar to the $\Delta \varepsilon$-values determined when the same $\alpha$-amylase (Figure 5 , bottom) and chicken pancreatic $\alpha$-amylase (2) are complexed by wheat $\alpha$-amylase inhibitors. In contrast to PAPI, the wheat inhibitors contain tryptophan (17) which may explain the difference in shapes of the respective difference spectra. 


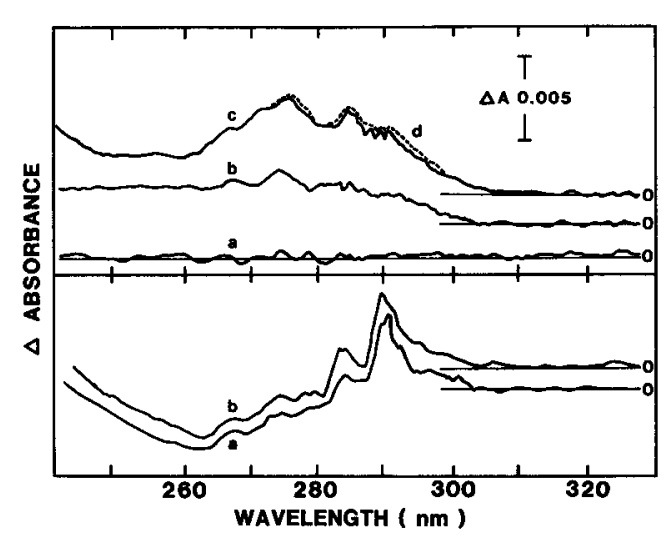

Figure 5. UV-difference spectra of porcine pancreatic $\alpha$-amylase $(9 \mu \mathrm{M})$ perturbed by increasing amounts of PAPI (top): a. $0 \mu \mathrm{M} ;$ b. $7 \mu \mathrm{M}$; c. $14 \mu \mathrm{M}$; d. $21 \mu \mathrm{M}$ (- - ) and wheat $\alpha$-amylase inhibitors (unfractionated) (bottom): a. $16 \mu \mathrm{M}$, b. $32 \mu \mathrm{M}$.

Our inability to find a carbohydrase and/or protease which PAPI inhibits can be explained in at least three ways. First, the protein is an inhibitor which is specific for target enzyme(s) which we have yet to identify. This problem of target enzyme specificity is apparent from work on various members of what is named the serpins $(6,7)$. Thus ovalbumin (11) and a barley seed albumin, $Z$ protein (10), belong to the serpin family and have no known target enzymes. Furthermore, although shown to inhibit trypsin in vitro, the plasma protease inhibitors of the same family do not function in vivo as inhibitors of this enzyme. Second, we may speculate that PAPI has no longer a functional active site. No data support this contention for the $\alpha$-amylase inhibition because the reactive site has not been identified in the homologous ragi inhibitor, I-2. However, the inability of PAPI to inhibit trypsin or related proteases was suggested to be due to changes in the amino acid residues in two of the three possible protease reactive sites seen in the homologous plant trypsin inhibitors (25). Third, since difference UV-spectroscopy indicates that formation of a complex between PAPI and pancreas $\alpha$-amylase takes place, one may suggest that PAPI has a role in controlling another property than enzymic activity of this and perhaps other $\boldsymbol{\alpha}$-amylases.
Furthermore, it has been pointed out that, due to their genome size and replicative precision, higher organisms maintain and express genes whose products are functionally redundant or inactive (27). In cereals, such dispensible genes might be found among the gene families encoding enzyme inhibitors, in particular proteins of the barley trypsin inhibitor family $(21,26)$ which are dispersed in small, multigene groups (18). In fact, members of this family have either no known target enzyme or are inhibitors of various $\alpha$-amylases and/or proteases (1), and at least one branch of their ancestral line appears to have evolved into a noninhibitory domain of the major prolamin seed storage proteins $(28)$.

\section{ACKNOWLEDGEMENTS}

We are grateful to Professor M. OTTESEN and Fil.dr. L. MUNCK for support and helpful suggestions. Drs. G. Fincher, M. BallanCE, K. BREDDAM and T. DREYER are thanked for help with assays for hydrolase inhibition. Mss. B. CoRNELIUSSEN, L. SøRENSEN and B. Fløistrup are acknowledged for excellent technical assistance.

\section{REFERENCES}

1. Barber, D., R. Sanchez-Mouge, E. Mendez, A. Lazaro, F. Garcia-Olmedo \& G. Salcedo: New $\alpha$-amylase and trypsin inhibitors among the CMproteins of barley (Hordeum vulgare L.). Biochim. Biophys. Acta 869, 115-118 (1986)

2. Buonocore, V., P. Giardina, R. Parlamenti, E. POERIO \& V. SILANO: Characterization of chicken pancreas $\alpha$-amylase isozymes and interaction with protein inhibitors from wheat kernel. J. Sci. Food Agric. 35, 225-232 (1984)

3. Breddam, K., S. B. Sørensen \& M. OtTesen: Isolation of a carboxypeptidase from malted barley by affinity chromatography. Carlsberg Res. Commun. 48, 217-230 (1983)

4. CAMPos. F. A. P. \& M. Richardson: The complete amino acid sequence of the bifunctional $\alpha$-amylase/trypsin inhibitor from seeds of ragi (Indian finger millet, Eleusine coracana Gaertn. ). FEBS Letters 152, 300-304 (1983)

5. Campos, F. A. P.\& M. Richardson: The complete amino acid sequence of $\alpha$-amylase inhibitor I-2 from seeds of ragi (Indian finger millet, Eleusine 
coracana Gaertn. ). FEBS Letters 167, 221-225 (1984)

6. Carrell. R. W..J.-O.Jeppsson, C.-B. Laurell.S.O Brennan, M. C. OWen, L. Vaughan \& D. R. BOSWELL: Structure and variation of human $\alpha_{1}$-antitrypsin. Nature 298, 329-334 (1982)

7. Carrell. R. \& J. Travis: $\boldsymbol{\alpha}_{1}$-Antitrypsin and the serpins: variations and countervariations. Trends Biochem. Soc. 10, 20-24 (1985)

8. Dreyer. T. K. BiedermanN \& M. Ottesen: Yeast proteinase in beer. Carlsberg Res. Commun. 48, 249-253 (1983)

9. Heijne. G. von: Patterns of amino acids near signal-sequence cleavage sites. Eur. J. Biochem. 133, 17-21 (1983)

10. Hejgaard. J.. S. K. Rasmussen, A. Brandt \& I SVENDSEN: Sequence homology between barley endosperm protein $Z$ and protease inhibitors of the $\alpha_{1}$-antitrypsin family. FEBS Letters 180, 89-94 (1985)

11. HUNT. L. T. \& M. O. Dayhoff: A surprising new protein superfamily containing ovalbumin, antithrombin-III, and $\alpha_{1}$-proteinase inhibitor. Biochem. Biophys. Res. Commun. 95, 864-871 (1980)

12. Johansen. J. T. K. BReddaM \& M. OtTesen: Isolation of carboxypeptidase $\mathrm{Y}$ by affinity chromatography. Carlsberg Res. Commun. 41, 1-14 (1976)

13. Johansen. J. T... C. Overballe-Petersen, B. Martin. V. Hasemann \& I. SVEndsen: The complete amino acid sequence of copper, zinc superoxide dismutase from Saccharomyces cerevisiae. Carlsberg Res. Commun. 44, 201-217 (1979)

14. JONASSEN, I.: Characteristics of Hiproly barley I. Isolation and characterisation of two water-soluble high-lysine proteins. Carlsberg Res. Commun. 45 , 47-58 (1980)

15. JONASSEN. I \& I. SVENDSEN: Identification of the reactive sites in two homologous serine proteinase inhibitors isolated from barley. Carlsberg Res. Commun. 47, 199-203 (1982)

16. Joubert. F. J.. H. Kruger, G. S. TOWNSHEND \& D. P. BOTES: Purification, some properties and the complete primary structures of two protease inhibitors (DE-3 and DE-4) from Macrotyloma axillare seed. Eur. J. Biochem. 97, 85-91 (1979)

17. Kashlan, N. \& M. Richardson: The complete amino acid sequence of a major wheat protein inhibitor of $\alpha$-amylase. Phytochemistry 20, 17811784 (1981)

18. KReis, M., B. G. Forde, S. Rahman, B. J. Mifuin \& P. R. SHEWRY: Molecular evolution of the seed storage proteins of barley, rye and wheat. J. Mol. Biol. 183, 499-502 (1985)

19. LAEMMLI, U. K.: Cleavage of structural proteins during the assembly of the head of bacteriophage T4. Nature 227, 680-685 (1970)

20. LASKOWSKI, JR., M. \& I KaTO: Protein inhibitors of proteinases. Ann. Rev. Biochem. 49, 593-626 (1980)

21. LaZaro, A., D. Barber, G. SalCedo, E. MENDEZ \& F. Garcia-OlmEdo: Differential effects of highlysine mutations on the accumulation of individual members of a group of proteins encoded by a disperse multigene family in the endosperm of barley (Hordeum vulgare L. ). Eur. J. Biochem. 149, 617-623 (1985)

22. MAHONEY, W. C., M.A. HeRmodson, B. Jones, D. P. POWERS. R. S. CORFMAN \& G. R. REECK: Amino acid sequence and secondary structural analysis of the corn inhibitor of trypsin and activated Hageman factor. J. Biol. Chem. 259, 8412-8416 (1984)

23. Mundy. J., I. Svendsen \& J. HejgaARd: Barley $\alpha$-amylase/subtilisin inhibitor. 1. Isolation and characterization. Carlsberg Res. Commun. 48, 81-90 (1983)

24. Mundy, J., J. HejgaARd \& I. Svendsen: Characterization of a bifunctional wheat inhibitor of endogenous $\alpha$-amylase and subtilisin. FEBS Letters 167 , 210-214 (1984)

25. MUNDY, J. \& J. C. RoGers: Selective expression of a probable amylase/protease inhibitor in barley aleurone cells: Comparison to the barley amylase/ subtilisin inhibitor. Planta 169, 51-63 (1986)

26. OdANi, S., T. KoIde \& T. ONO: The complete amino acid sequence of barley trypsin inhibitor. J. Biol. Chem. 258, 7998-8003 (1983)

27. OHNo, S.: Dispensable genes. Trends in Gen. 1, 160-164 (1985)

28. Paz-Arez. J., F. Ponz, P. Rodriguez-Palenzuela. A. Lázaro, C. Hernández-lucas, F. GarciaOLMEDO\& P. CARBONERO: Characterization of $\mathrm{CD}$ NA clones of the family of trypsin/ $\alpha$-amylase inhibitors (CM-proteins) in barley (Hordeum vulgare L. ). Theor. Appl. Genet. 71, 842-846 (1986)

29. RICHARDSON, M.: The complete amino acid sequence and the trypsin reactive (inhibitory) site of the major proteinase inhibitor from the fruits of aubergine (Solanum melongena L. ). FEBS Letters 104, 322-326 (1979)

30. Shewry, P. R., D. Lafiandra, G. Salcedo, C. ARagoncillo, F. Garcia-Olmedo. E. J.-L. Lew, M. D. DieTLER \& D. D. KASARDA: N-terminal amino acid sequences of chloroform/methanol-soluble proteins and albumins from endosperms of wheat, barley and related species. FEBS Letters 175, 359-363 (1984)

31. Shivaraj, B. \& T. N. Pattabiraman: Natural plant enzyme inhibitors. Characterization of an unusual $\alpha$-amylase/trypsin inhibitor from ragi Eleusine 
coracana Gaertn. ). Biochem J. 193, 29-36 (1981)

32. SvendSEN, I.,B. MARTIN\& I. JonasSen: Characteristics of Hiproly barley III. Amino acid sequences of two lysine-rich proteins. Carlsberg Res. Commun. $45,79-85$ (1980)

33. SvendSen, I., I Jonassen, J. HejgaARd \& S. Boisen: Amino acid sequence homology between a serine protease inhibitor from barley and potato inhibitor

I. Carlsberg Res. Commun. 45, 389-395 (1980)

34. Svensson, B., K. LaRSen \& I Svendsen: Amino acid sequence of tryptic fragments of glucoamylase G1 from Aspergillus niger. Carlsberg Res. Commun. 48, 517-527 (1983)

Accepted by S.O. ANDERSEN 